Bangladesh J. Bot. 48(1): 53-63, 2019 (March)

\title{
MORPHOLOGICAL AND ANATOMICAL INVESTIGATION OF THREE SCANDIX SPECIES FROM TURKEY
}

\author{
Azize Demirpolat ${ }^{1}$, Gulden Dogan* and Eyup Bagci \\ Department of Biology, Faculty of Science, Firat University, Elazig, Turkey \\ Keywords: Scandix, Morphology, Anatomy
}

\begin{abstract}
Morphological, morphometrical and anatomical features of some Scandix species (Scandix pectenveneris, $S$. macrorhyncha and $S$. balansae) were investigated to compare and determine the taxonomic importance of these characters. Description, synonyms, Turkish names, flowering times, habitat properties and anatomical structure of each species were determined. According to morphological and anatomical characters $S$. macrorhyncha and $S$. pecten-veneris showed high-level similarity. However, endemic $S$. balansae showed distinct both morphological and anatomical differences from the other Scandix species.
\end{abstract}

\section{Introduction}

Apiaceae (Umbelliferae) is the third largest family in terms of genera in Turkish Flora. It is also the eighth largest family with approximately 455 species, and $33 \%$ of them are endemic (Davis et al. 1988, Guner et al. 2000, Urusak and Kizilarslan 2013).

Apiaceae species have specific odours because they have secretory cavities (vittae), which are schizogenous oil ducts with resin, oil, or mucilage. They are found in the roots, petioles, stems, leaves, and fruits (Metcalfe and Chalk 1979, Pluinkett et al. 2014). In the family Apiaceae, morphological and anatomical fruit characteristics and the number of vittae have reliable diagnostic importance (Urusak and Kizilarslan 2013). Morphological and anatomical studies have increased over the last few years (Selvi et al. 2013, Bakis and Babac 2014, Bayirli et al. 2014, Ozcan and Eminagaoglu 2014, Satil et al. 2015, Cavusoglu and Karaferyeli 2015). However studies on the morphology and anatomy of this genus Scandix have not been found. Metcalfe and Chalk (1950) and Watson and Dallwitz (2000) explained the anatomical characteristic properties of the family Apiaceae.

The genus Scandix L. contains 20 species of them 15 are mostly confined to the Mediterranean region (Zohary 1972, Kubeczka 1982, Downie et al. 2000) and only Scandix pecten-veneris L. is widely distributed (Cohen 2002). It is represented by 8 species and 9 taxa in Flora of Turkey. Scandix pecten-veneris L., Scandix macrorhyncha C.A. Meyer and Scandix balansae Reuter ex Boiss. are annual herbs and S. balansae is an endemic species in Flora of Turkey (Davis 1972). Scandix pecten-veneris is called as "Kişkiş, Zühre tarağı" S. macrorhyncha "Leylek otu" and S. balansae also "Ördek burnu" as Turkish name (Baytop 1997). The genus Scandix is dibasic $(\mathrm{x}=7,8)$ in nature with $\mathrm{x}=8$ being the most common basic number (Jeelani et al. 2012).

The consumption of wild plants such as $S$. pecten-veneris in Greece has been documented for more than two thousand years. Scandix is mentioned as a pot-herb by Theophrastus and Pliny, and Dioscorides describes the greens as being eaten raw or cooked. Euripides's mother was supposed to have sold wild chervil on the Athenian market. The wild plants that Turkish ancestors used to

*Author for correspondence: <gdogan@ firat.edu.tr>. ${ }^{1}$ Bingol University, Technical Science Vocational High School, Bingöl, Turkey. 
collect (there are reports by Theophrastus, and by Dioscorides) and use in separate dishes are present even today in meals, mostly in villages (Psaroudaki et al. 2012). According to Dodonoeus, writing in 1578, "Scandix eaten is good and wholesome, and in times past had been a common herb amongst the Greeks, but of small estimation and value, and taken but only for a wild wurt or herb" (Hulme 1902).

Tsakalidi (2014) reported that $S$. pecten-veneris is a species which grows in arable land and waste places and prospers in sandy, loam, clay soils. It is grown from seeds, mainly during autumn and early winter, although a few seeds germinate in spring in cultivated fields. The leaves are the main edible parts of the plant and are either consumed boiled by just adding olive oil, or in pies. $S$. pecten-veneris contains minerals, fatty acids and fibres, phenols and alpha-tocopherol. It can be used as a model species for the extensive study of climate changes since it was once widespread and often abundant in the lowlands, but its growth has considerably declined lately due to the introduction of chemical herbicides, fertilizers and the destruction of field margins (Tsakalidi 2014).

The purpose of this study is to give a detailed account of the morphological, morphometrical and anatomical features of the some Scandix species growing in Turkey. It is expected that it will provide an important information to the taxonomic studies as monograph and will contribute for further investigation in future.

\section{Materials and Methods}

Plant specimens were collected during the flowering and fruiting periods from natural populations in different regions from Turkey (2014 - 2015). Some individuals were used for morphological and anatomical observations and some of them were dried and stored as herbarium samples. The voucher specimens have been deposited at the Firat University Herbarium (FUH 8012, 8014, 8015, 8016, 8020, 8021).

The taxonomic description of the plant was prepared according to Flora of Turkey (Davis 1972). Collection locations, collector's number and the habitat of investigated samples are presented in Table 1 and distribution in Fig. 1. The morphological and morphometrical characters are presented in Table 2. The photographs in nature and illustrations of the descriptive characters are shown in Fig. 2.

Anatomical studies were carried out on specimens fixed in $70 \%$ alcohol. Cross sections were applied to the stem, root and fruits of the plant samples studied and the observations were carried out on these characters by light microscope "Olympus BX51" and photographed. The microanatomical measurements are presented in Table 3 and anatomical features in Fig. 3.

Table 1. The locality informations of collected Scandix species.

\begin{tabular}{ll}
\hline Species & Locality \\
\hline $\begin{array}{l}\text { Scandix } \\
\text { pecten-veneris }\end{array}$ & $\begin{array}{l}\text { B6 Malatya, Venk Köyü, 1300 m, Demirpolat 1023; B7 Tunceli, Çemişgezek Köyü, } \\
1000 \text { m, Demirpolat 1028; B6 Kahramanmaraş, Pazarcık, Ketiler köyü, 750 m, } \\
\text { Demirpolat 1039; C5 Mersin, Buluklu } 1500 \text { m, Demirpolat 1038. }\end{array}$ \\
$\begin{array}{l}\text { Scandix } \\
\text { macrorhyncha }\end{array}$ & C6 Gaziantep, Edilii-Koçcağız köyü, 1100 m, Demirpolat 1024. \\
$\begin{array}{l}\text { Scandix } \\
\text { balansae }\end{array}$ & C5 Mersin, Fındıkpınarı, Çapurgediği, 1200 m., Demirpolat 1030. \\
\hline
\end{tabular}




\section{Results and Discussion}

The morphological descriptions of Scandix species studied are compared with the Flora of Turkey (Davis 1972). Descriptions of morphological and morphometrical characters were expanded with the detailed investigations on the recent collections (Table 2).

Table 2. Morphological and morphometrical characters of Scandix species.

\begin{tabular}{|c|c|c|c|}
\hline \multirow{2}{*}{ Characters } & \multicolumn{3}{|c|}{ Plants } \\
\hline & S. pecten-veneris & S. macrorhyncha & S. balansae \\
\hline Plant & $19-40 \mathrm{~cm}$ & $18-30 \mathrm{~cm}$ & $12-25 \mathrm{~cm}$ \\
\hline Length of rays & $1-2 \mathrm{~mm}$ & $1-2 \mathrm{~cm}$ & $0.5-1.2 \mathrm{~cm}$ \\
\hline Number of mature rays & $1-3$ & $1-3$ & $3-5$ \\
\hline Hairs of mature rays & Scarce hairs & Dense hairs & Scarce hairs \\
\hline Bracteoles & Apex of two toothed & Entire & Apex of two toothed \\
\hline Number of bracteol & $4-7$ & $4-8$ & $3-6$ \\
\hline Hairs of bracteoles & Dense hairs & Scarce hairs & Scarce hairs \\
\hline Width of bracteol & $1-2 \mathrm{~mm}$ & $1-2 \mathrm{~mm}$ & $1 \mathrm{~mm}$ \\
\hline Length of bracteol & $4-9 \mathrm{~mm}$ & $3-8 \mathrm{~mm}$ & $1.5-3 \mathrm{~mm}$ \\
\hline Colours of flower & White & White & White \\
\hline Number of fruit & $4-16$ & $5-17$ & $7-13$ \\
\hline Length of mature fruit & $3-5 \mathrm{~cm}$ & $3-6 \mathrm{~cm}$ & $0.5-0.75$ \\
\hline Width of mature fruit & $1-2 \mathrm{~mm}$ & $1-2 \mathrm{~mm}$ & $0.5-1 \mathrm{~cm}$ \\
\hline Colours of dorsally ridges in fruit & Dark brown-green & Dark brown-green & Light greenish to brown \\
\hline Fruit shapes & Linear & Linear & Linear \\
\hline Beak length of the fruit & $0.5-1 \mathrm{~mm}$ & $0.5-1 \mathrm{~mm}$ & $0.2-0.5 \mathrm{~mm}$ \\
\hline Length of pedicel & $0.5-1 \mathrm{~mm}$ & $3-5 \mathrm{~mm}$ & $2-5 \mathrm{~mm}$ \\
\hline Styles length of fruit & $0.5-0.7 \mathrm{~mm}$ & $2-2.5 \mathrm{~mm}$ & $0.5-1 \mathrm{~mm}$ \\
\hline Width of petal & $1.2 \mathrm{~mm}$ & $0.8 \mathrm{~mm}$ & $1 \mathrm{~mm}$ \\
\hline Length of petal & $1-1.5 \mathrm{~mm}$ & $0.5-1.1 \mathrm{~mm}$ & $0.5-1 \mathrm{~mm}$ \\
\hline Leaf shapes & Pinnat-pinnatisect & Pinnat-pinnatisect & Pinnat-pinnatisect \\
\hline Width of leaf & $1-3,5 \mathrm{~cm}$ & $1-4 \mathrm{~cm}$ & $0,5-2 \mathrm{~cm}$ \\
\hline Length of leaf & $3-8 \mathrm{~cm}$ & $2-9 \mathrm{~cm}$ & $2-5 \mathrm{~cm}$ \\
\hline Length of petiole & $1.5 \mathrm{~mm}$ & $1.5 \mathrm{~mm}$ & $1 \mathrm{~mm}$ \\
\hline Hairs of petiole & Simple hairy & Simple hairy & Not hairy \\
\hline
\end{tabular}

\section{Scandix pecten-veneris $\mathrm{L}$.}

Description: Plant almost erect, glabrous, pilose or setose, $19-40 \mathrm{~cm}$. Leaves oblong to oblong-ovate, 2(-3)-pinnate or pinnatisect, $3-8 \times 1-3.5 \mathrm{~cm}$. Rays $1-3$, usually equal, $1-2 \mathrm{~cm}$ long. Bracteoles $4-9 \times 1-2 \mathrm{~mm}$. Pedicels $2-7$, almost equal, $2-4 \mathrm{~mm}$. Fruit usually scabrid, 3 $5 \mathrm{~cm} \times 1-2 \mathrm{~mm}$, beak gradually attenuate to apex, dorsally compressed, $1.5-2.5 \mathrm{~mm}$ long. Ridges brownish-green, usually as broad as broder than dark valleculae. Fl. 3 - 6; Habitat; Dry and hard top edges eroded slope, Pinus and Populus plantation, edge of wheat fields roadsides, stepper volcanic slopes, road-banks and cornfields, $300-1150 \mathrm{~m}$. Turkish name; Zühre tarağı. 


\section{Scandix macrorhyncha C.A. Meyer}

$=$ S. pecten-veneris L. subsp. macrorhyncha (C.A. Meyer) Rouy \& Camus, Fl. Fr. 7 : 299 (1901)

Description: Plant erect, glabrous, pilose or setose, $18-33 \mathrm{~cm}$. Leaves oblong to oblongovate, 2(-3)-pinnate or pinnatisect, $2-9 \times 1-4 \mathrm{~cm}$. Rays $1-3$, usually equal, $1-2 \mathrm{~cm}$ long. Bracteoles $3-8 \times 1-2 \mathrm{~mm}$. Pedicels $2-7$, almost equal, $2-6 \mathrm{~mm}$. Fruit usually scabrid, $3-6 \mathrm{~cm}$ $\times 1-2 \mathrm{~mm}$, beak gradually attenuate to apex, dorsally compressed, $1-2.5 \mathrm{~mm}$ long. Ridges brownish-green, usually as broad as broder than dark valleculae. Fl. 4 - 6; Habitat; Dry and hard top edges eroded slope, edge of wheat fields roadsides, stepper volcanic slopes, road-banks and cornfields, 300 - $2190 \mathrm{~m}$. Turkish name; Leylekotu.

\section{Scandix balansae Reuter ex Boiss.}

\section{= Scandix brachycarpa Boiss.}

= Selinum balansae (Reut. ex Boiss.) E. H. L. Krause

Description: Slender, somewhat flexuose, glabrous or sparsely hispid plant, $12-25 \mathrm{~cm}$. Leaves ovate to triangular, 2 - 3-pinnate or pinnatisect, $2-5 \times 0.5-2 \mathrm{~cm}$, ultimate lobes linearlanceolate, $2-3 \times 1 \mathrm{~mm}$. Rays $3-5,0.5-1.2 \mathrm{~cm}$, thickening in fruit. Bracteoles $3-6$, entire to coarsely toothed from apex, $1.5-3.0 \times 1 \mathrm{~mm}$. Pedicels $5-14$, nearly equal, $2-5 \mathrm{~mm}$ in fruit. Fruit asperous or not, $0.5-1.0 \mathrm{~cm} \times 0.5-0.75 \mathrm{~mm}$, beak $0.2-0.5 \mathrm{~mm}$. Primary ridges broad. Fruting styles 0.5 - 1.0 mm. Fl. 4 - 5; Habitat; Grassy slopes, 1000 - 1293 m. Turkish name; Ördek burnu.

Distribution: Endemic, threat category: VU, Type: [Turkey C5 Icel] Gülek Boghas, Balansa $628(\mathrm{G} !)$.

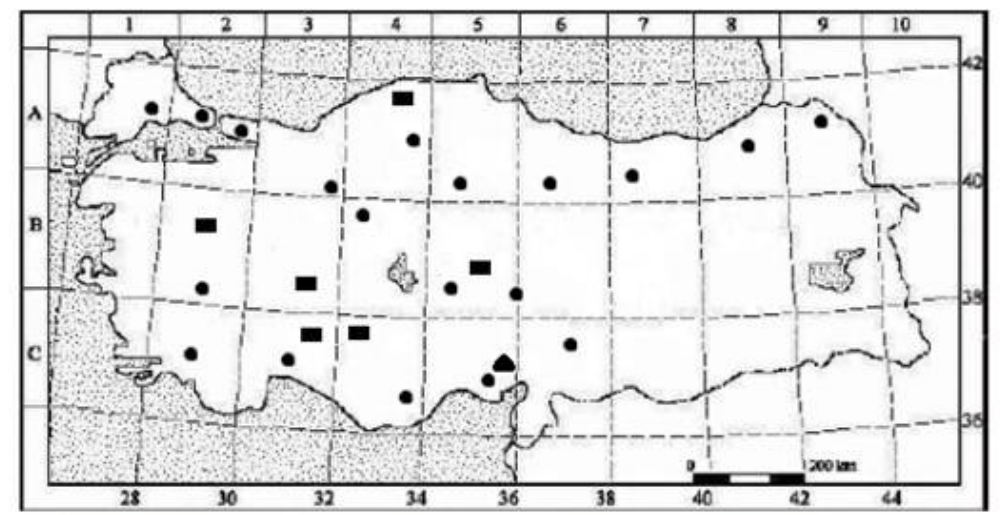

Fig. 1. Destrubution of studied Scandix species in Turkey (• S. pecten-veneris, - S. macrorhyncha, A S. balansae).

\section{Anotomy}

\section{Stem}

Scandix pecten-veneris: The epidermis is single layered and consists of mostly rectangular or ovoidal cells. The cortex is composed of $4-6$ layers and the cells are ovoidal.The first $2-3$ layers of cortex cells underneath the epidermis have chloroplasts, but the small, $1-2$ layers of cortex cells close to phloem have a few or no chloroplasts. There is chollenchima layer underneath the epidermis that is buried in the cortex at some places. Chollenchima is composed of 10 - 14 layers. The secretory canal consists of $4-8$ secretory cells is buried in the cortex, underneath the collenchima layer radially. There is a layer below the cortex paranchima composed of sclerenchymatic cells with thicker walls. Sclerenchymatic cells consist of 5-11 layers and 


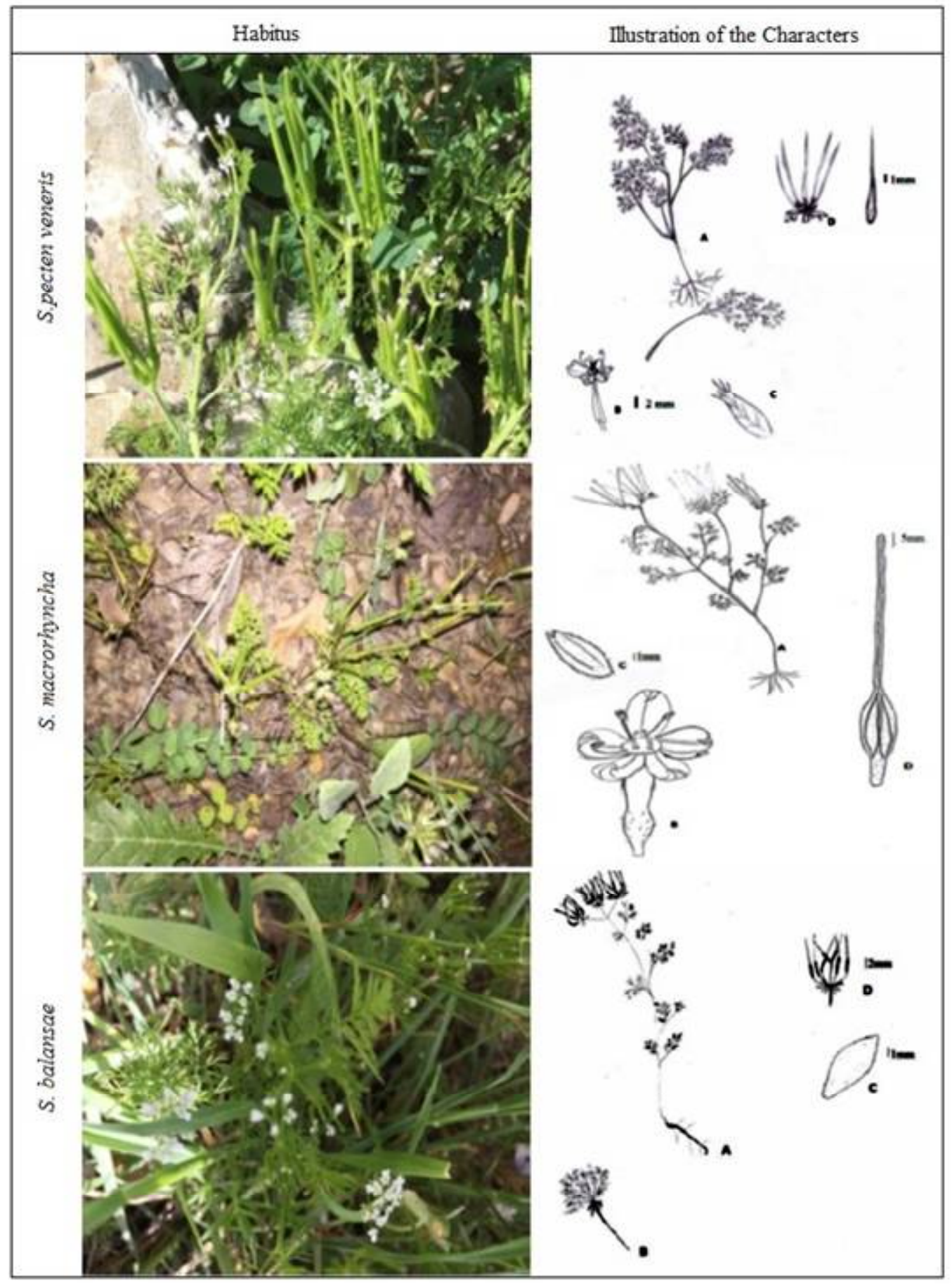

Fig. 2. Scandix species. A. General apperance. B. Flower. C. Bracteol and D. Fruit. 
intercellular spaces appeared between these cells. Phloem is composed of 7 - 12 layers of cells. Xylem is composed of 6 - 15 layers of cells. The major part of the stem is reserved by pith region. The paranchimatic cells of the pith region are either ovoidal or circular. The measurements of the stem are given in Table 3.

Scandix macrorhyncha: The epidermis is single layered and consists of mostly ovoidal cells. The cortex is composed of $4-6$ layers and the cells are ovoidal. The first $1-2$ layers of cortex cells underneath the epidermis have chloroplasts, but the small, 1 - 2 layers of cortex cells close to phloem have no chloroplasts and big. There is chollenchima layer underneath the epidermis that is buried in the cortex at some places. Chollenchima is composed of $10-14$ layers. The secretory canal consists of $4-8$ secretory cells is buried in the cortex, underneath the collenchima layer radially. There is a layer below the cortex paranchima composed of sclerenchymatic cells with thicker walls. Sclerenchymatic cells consist of 5-12 layers and intercellular spaces appeared between these cells. Phloem is composed of $7-12$ layers of cells. Xylem is composed of 6 - 15 layers of cells. The major part of the stem is reserved by pith region. The paranchimatic cells of the pith region are either ovoidal or circular. The measurements belong to the stem are given in Table 3 .

Scandix balansae: The epidermis is single layered and consists of mostly rectangular or ovoidal rectangular cells. The cortex is composed of $3-5$ layers and the cells are ovoidal. The first 2 - 3 layers of cortex cells underneath the epidermis have chloroplasts, but the small, 3 - 5 layers of cortex cells close to phloem have few chloroplasts. There is chollenchima layer underneath the epidermis that is buried in the cortex at some places. Chollenchima is composed of $11-12$ layers. The secretory canal consists of $5-8$ secretory cells is buried in the cortex, underneath the collenchima layer radially. There is a layer below the cortex paranchima composed of sclerenchymatic cells with thicker walls. Sclerenchymatic cells consist of $3-5$ layers and intercellular spaces appeared between these cells. Phloem is composed of $3-8$ layers of cells. Xylem is composed of 3 - 8 layers of cells. The major part of the stem is reserved by pith region. The paranchimatic cells of the pith region are either ovoidal or circular. The measurements of the stem are given in Table 3.

\section{Root}

Scandix pecten-veneris: The periderm in the root is composed of 2 - 3 layered rectangular cells. Cortex cells are arranged underneath. Secretory canals consist of $4-6$ cells could be found within the cortex and phloem. Phloem and xylem layers are arranged beneath the endodermis. Phloem is composed of 9 - 15 layers of cells. One layer of cambium is located between phloem and xylem. The major part of the root is reserved by xylem. The pith region is composed of paranchimatic cells. The measurements of the root are given in Table 3.

Scandix macrorhyncha: The periderm in the root is composed of 2 - 3 layered rectangular cells. Cortex cells are arranged underneath. Secretory canals consist of $4-6$ cells could be found within the cortex and phloem. Phloem and xylem layers are arranged beneath the endodermis. Phloem is composed of $8-19$ layers of cells. One layer of cambium is located between phloem and xylem. The major part of the root is reserved by xylem. The pith region is composed of paranchimatic cells. The measurements belong to the root are given in Table 3.

Scandix balansae: The periderm in the root is composed of 2 - 3 layered rectangular cells. Cortex cells are arranged underneath. Between cortex cells consist intercellular spaces. Secretory canal absent within the cortex and phloem. Phloem and xylem layers are arranged beneath the endodermis. Phloem is composed of 3 - 5 layers of cells. 1 - 2 layers of cambium are located between phloem and xylem. The major part of the root is reserved by xylem. Trachea and tracheids are regularly arranged within the secondary xylem. Supportive sclerenchymatic cells are 
located between these cells. The arms of pith composed of paranchimatic cells are arranged radially. The pith region is composed of paranchimatic cells. The measurements of the root are given in Table 3.

Table 3. Comparative micro-anatomical measurements of various tissues of investigated Scandix species.

\begin{tabular}{lccl}
\hline & S. pecten-veneris & S. macrorhyncha & S. balansae \\
\hline Stem & $7-28$ & $7-29$ & \\
Epidermis cell width $(\mu \mathrm{m})$ & $5-10$ & $5-10$ & $4-30$ \\
Epidermis cell length $(\mu \mathrm{m})$ & $6-35$ & $6-35$ & $5-25$ \\
Cortex cell width $(\mu \mathrm{m})$ & $7-38$ & $7-35$ & $5-28$ \\
Cortex cell length $(\mu \mathrm{m})$ & $23-105$ & $25-105$ & $18-96$ \\
Pith cell width $(\mu \mathrm{m})$ & $17-112$ & $16-112$ & $12-98$ \\
Pith cell length $(\mu \mathrm{m})$ & $65-90$ & $68-92$ & $35-65$ \\
Cortex cell layer $(\mu \mathrm{m})$ & & & \\
Root & $16-51$ & $15-5$ & $15-55$ \\
Chortex cell width $(\mu \mathrm{m})$ & $6-15$ & $6-14$ & $6-14$ \\
Chortex cell length $(\mu \mathrm{m})$ & $38-81$ & $40-80$ & $10-12$ \\
Periderma thickness $(\mu \mathrm{m})$ & & & \\
Fruit & $5-9$ & $5-8$ & $4-5$ \\
Mericarp width $(\mathrm{mm})$ & $11-13$ & $11.4-13$ & $15-17$ \\
Exocarp thickness $(\mu \mathrm{m})$ & $2-4$ & $2-4$ & $2-3$ \\
Mesocarp cell & $12-17$ & $11.7-16.4$ & $9-12$ \\
Mesocarp thickness $(\mu \mathrm{m})$ & 16 & 15.6 & 12 \\
Endocarp thickness $(\mu \mathrm{m})$ & 1 & 1 & 3 \\
Dorsal vittae number & $1-2$ & $1-2.4$ & $0.3-0.7$ \\
Dorsal vittae width $(\mathrm{mm})$ & 2 & 2 & 6 \\
Dorsa-lateral vittae number & $1-2$ & $1-2.2$ & $0.25-0.30$ \\
Dorsa-lateral vittae width $(\mathrm{mm})$ & 2 & 2 & 6 \\
Komissural vittae number & $1-2.4$ & $1.3-2.7$ & $0.30-0.30$ \\
Komissural vittae width $(\mathrm{mm})$ & $3.2-4.3$ & $3.6-4.0$ & - \\
Endosperm width $(\mathrm{mm})$ & & & \\
\hline & & &
\end{tabular}

\section{Fruit}

Scandix pecten-veneris: Fruits are composed of two mericarps. At the cross-section of fruit mericarp, mericarp has determined as bean-shaped. The mericaps are attached to each other at the carpophore ventrally. Each mericarp is compressed towards the wings and its ventral is circleshaped at the center. Exocarp consists of 1 layer flat rectangular-like cells. Mesocarp consists of 2 - 4 layers of flat-ovoidal cells. The different sizes of the cells constitute the mesocarp are paranchimatic. Testa is composed of flat cells located beneath the endocarp. 1 dorsal vittae and 2 dorso-lateral vittae is arranged within mesocarp at the dorsal of mericarp. Two comissural vittae are located within mesocarp ventrally. The width of commissural vittae is higher than dorsal vittae. Resin canals in the commissural side are closed to carpophore. Endosperm is arranged at the center filling the pericarp. Tighly arranged endosperm cells are ovoidal or circular shaped. The measurements of the fruit are given in Table 3. 


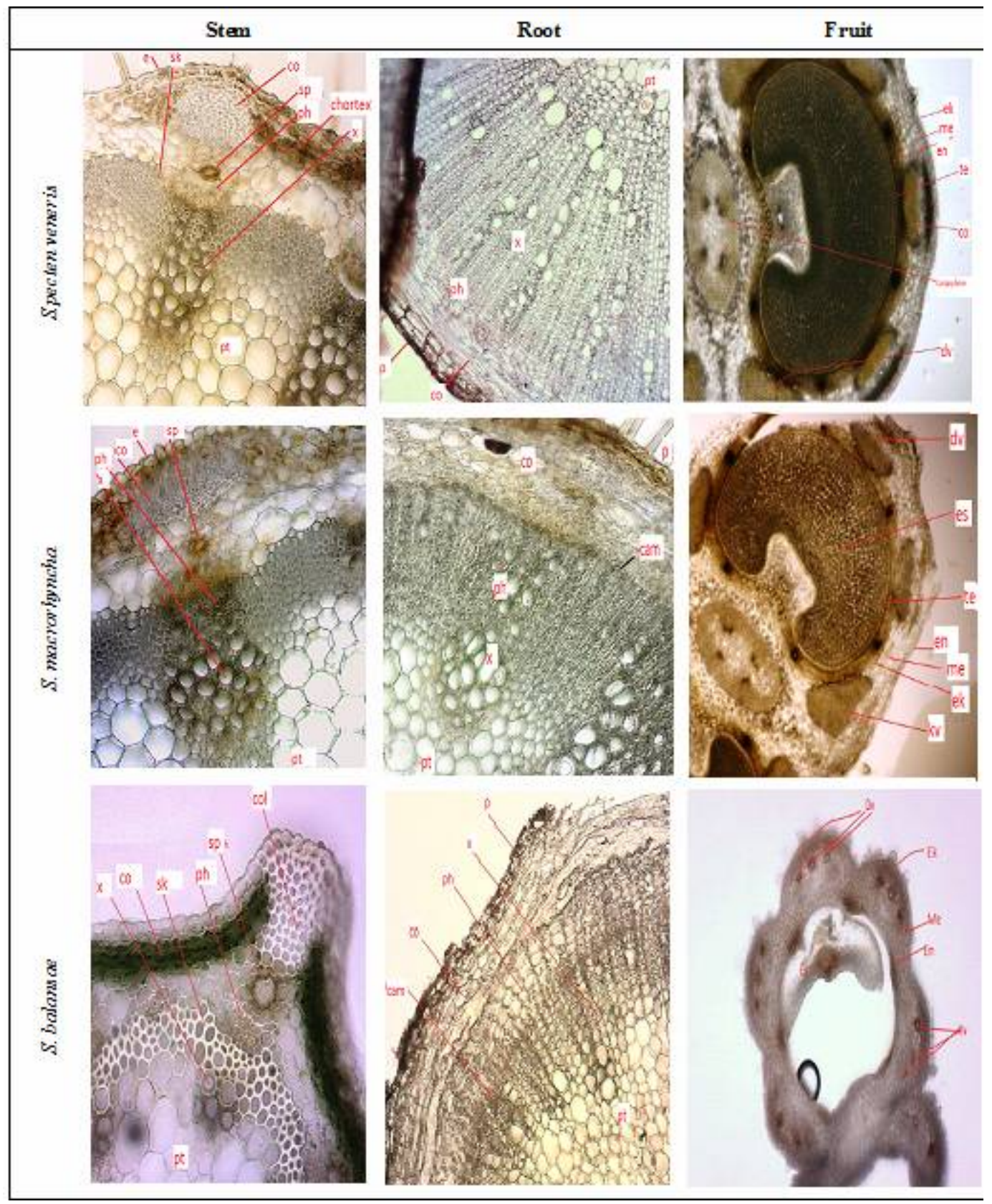

Fig. 3. Stem, root and fruit anatomy of studied Scandix species (e: epidermis, co: collenchyma, cam: cambium; x: xylem, ph: phloem, pt: pith region, p: periderma, sp: secretory pocket, sk: sclerenchyma; ek: ektodermis, en: endodermis, me: mesodermis, dv: dorsal vittae, kv: komissural vittae, te: testa).

Scandix macrorhyncha: Fruits are composed of two mericarps. At the cross-section of fruit mericarp, mericarp is bean-shaped. The mericaps are attached to each other at the carpophore 
ventrally. Each mericarp is compressed towards the wings and its ventral is circle-shaped at the center. Exocarp consists of 1 layer flat rectangular-like cells. Mesocarp consists of 2 - 4 layers of flat-ovoidal cells. The different sizes of the cells constitute the mesocarp are paranchimatic. Testa is composed of flat cells located beneath the endocarp. One dorsal vittae and 2 dorso-lateral vittae are arranged within mesocarp at the dorsal of mericarp. Two comissural vittae are located within mesocarp ventrally. The width of commissural vittae is higher than dorsal vittae. Resin canals in the commissural side are closed to carpophore. Endosperm is arranged at the center filling the pericarp. Tightly arranged endosperm cells are ovoidal or circular shaped. The measurements of the fruit are given in Table 3.

Scandix balansae: Fruits are composed of two mericarps. At the cross-section of fruit mericarp, mericarp is flat-circular shaped. The mericaps are attached to each other at the carpophore ventrally. Each mericarp is compressed towards the wings and its ventral is circleshaped at the center. Exocarp consists of 1 layer flat rectangular-like cells. Mesocarp consists of 2 - 3 layers of flat-ovoidal cells. The different sizes of the cells constitute the mesocarp are paranchimatic. Testa is composed of flat cells located beneath the endocarp. Three dorsal vittae and 6 dorso-lateral vittae is arranged within mesocarp at the dorsal of mericarp. Six comissural vittae are located within mesocarp ventrally. The width of commissural vittae is higher than dorsal vittae. Resin canals in the commissural side are closed to carpophore. Endosperm at the center did not completely fill the pericarp. The measurements of the fruit are given in Table 3 .

In this study, morphological, morphometrical and anatomical features of three species of Scandix genus were investigated. This study firstly reports some of the morphologic and morphometric characters not indicated in the Flora of Turkey and they used as additional characters for the Scandix genus patterns description. These characters are number of mature fruits per ray, beak length of the fruit, the position of the styles in the fruit, pedicel length, width and length of petal (Table 2).

According to this study, S. macrorhyncha and S. pecten-veneris showed high-level similarity. This situation matches with the description in the Flora of Turkey. The most important and selective morphological character of S. macrorhyncha is the bracteole character. The bracteoles of this species are inconspicuous, soon deciduous and entire. This species is commonly confused with $S$. pecten-veneris, but is easily distinguished since $S$. pecten-veneris has conspicuous, persistent and usually toothed bracteoles. Another difference is that beak of fruit from S. pectenveneris is strongly compressed, while that of $S$. macrorhyncha lightly compressed.

Height of the plant is max. $40 \mathrm{~cm}$ of the individuals of S. pecten-veneris. In the studies of Storkey et al. it is remarked to reach $50 \mathrm{~cm}$ (Storkey et al. 2010). This difference could stem from the different habitats of the plants. Coulter and Rose (1889) on the other hand, indicated S. pectenveneris leaves as $2-3$ linear pinnate, and petal height as $1-2 \mathrm{~mm}$. These results show highly similarity with present results.

According to Cohen, taxonomical characteristics of S. pecten-veneris include: bracteoles are 4 - $10 \mathrm{~mm}$ in height, and $2-4 \mathrm{~mm}$ in width, and the ray number in the ripe individuals are defined as 2 - 5. In our study, bracteole height and width is found as $4-9 \mathrm{~mm}$ and $1-2 \mathrm{~mm}$, respectively, while ray number is defined as $1-4$. When these results are compared, in Cohen's research, rail number is not counted less than 2. In this regard, some differences appear in the present study as compared to Cohen's. Cohen also indicated that two species not distributed in Turkey including $S$. pecten-veneris as sympatric with S. blepharicarpa and S. verna, He also identified that their populations sometimes mix in (Cohen 2002). In the present study pedicel and fruit lengths are defined as $2-4 \mathrm{~mm}$, and $3-5 \mathrm{~cm}$, respectively. However, Cohen indicated (2004) the pedicel length as $2-3 \mathrm{~mm}$, and the fruit length as $4-6 \mathrm{~cm}$. Tsakalidi pointed that fruit lenght of $S$. pecten- 
veneris could reach $6 \mathrm{~cm}$. In present study fruit length was max. $5 \mathrm{~cm}$ (Table 2). Furthermore, Tsakalidi indicated that $S$. pecten-veneris leaves are 2 - 3 pinnate consisting of linear segments (Tsakalidi 2014).

Within Scandix species, the weakest plant species is Scandix balansae. Fruit length of $S$. balansae is defined as $8-15 \mathrm{~mm}$ in the Flora of Turkey, parallel with Cohen (2004). In the present study fruit length is found as $5-12 \mathrm{~mm}$. Although this difference was quite minor, it is thought to be derived from the harvesting time.

Considering the anatomical results, S. pecten-veneris and S. macrorhyncha show differences in terms of some characters. They dissociate in terms of such differences as consisting oval epidermis cells (not circular), and periderm cell thickness as $38-81 \mu \mathrm{m}(27-74 \mu \mathrm{m})$. Root periderm of $S$. pecten-veneris is identified to be thicker than that of $S$. macrorhyncha.

Endemic plant species, namely $S$. balansae showed marked differences from the other Scandix species morphologically. These differences also reflected to the anatomical characters. It is the thinner plant species with $3-5$ cell lines in cortex $(35-65 \mu \mathrm{m})$. This species has $11-12$ collenchyma cell lines could be distinguished from consisting chloroplasts within cortex cells. The cross-section of fruits shows similarities with $S$. iberica with flattened-round mericarp (not flattened oval) mericarp width as $4-5 \mathrm{~mm}$ ( not $1-2 \mathrm{~mm}$ ), and exocarp thickness as $15-17 \mu \mathrm{m}$ (not $6-8 \mu \mathrm{m}$ ). S. balansae is the one with the highest vittae channel overall. While the other species consisting 5 vittae, this species is composed of 3 times more vittae (15 vittae).

Detailed morphological characteristics and anatomical structure of three Scandix species are given. The determined morphological properties in the present study are generally similar to the Flora of Turkey. But some differences were also observed. The anatomical features of Scandix species are reported for the first time in this study. The anatomical features of the stems, root and fruit of the Scandix species showed close similarities among each other.

\section{Acknowledgments}

The authors are grateful to Scientific Research Administration of Firat University for their financial supports.

\section{References}

Bakis Y and Babac MT 2014. Morphological variability of acorns and its taxonomic significance in Quercus from Turkey. Bangladesh J. Bot. 43(3): 293-299.

Bayırlı M, Selvi S and Cakılcioglu U 2014. Determining different plant leaves fractal dimensions: A new approach to taxonomical study of plants. Bangladesh J. Bot. 43: 275-283.

Baytop T 1997. Türkçe Bitki Adları Sözlüğü, pp. 571.

Cavusoglu K and Karaferyeli S 2015. Effects of Ginkgo biloba L. extract on the seed germination, seedling growth and leaf anatomy of barley under saline conditions. Bangladesh J. Bot. 44(1): 117-123.

Cohen O 2002. Studies on the genus Scandix L. (Apiaceae) I: Scandix verna spec nov The new identity of the common Scandix species in Israel. Israel J. Plant Scie. 50: 25-35.

Cohen O 2004. Studies on the genus Scandix L. (Apiaceae) II: Scandix blepharicarpa spec. nov. An endemic species from the basalt plateaus of northern Israel. Israel J. Plant Scie. 52: 59-63.

Coulter JM and Rose JN 1889. Notes on North American Umbelliferae, I.Botanical Gazette 14: 274-284.

Davis PH 1972. Flora of Turkey and the East Aegean Islands, Vol: 4, Edinburgh, UK: Edinburgh University Press, pp. 323.

Davis PH, Mill RR and Tan K (eds.) 1988. Centaurea L. In: Flora of Turkey and the East Aegean Islands, Vol: 10, Edinburgh, UK: Edinburgh University Press, pp. 151. 
Downie SR, Katz-Downie DS and Watson MF 2000. Phylogeny of the flowering plant family Apiaceae based on chloroplast DNA rpl16 and rpoc1 Intron sequences: Towards a suprageneric classification of subfamily Apioideae. Amer. J. Bot. 87(2): 273-292.

Guner A, Ozhatay N, Ekim T, Baser KHC eds. 2000. Flora of Turkey and the East Aegean Islands (Suppl II), Vol: 11, Edinburgh, UK: Edinburgh University Press.

Hulme FE 1902. Familiar Wild Flowers, Vol:3, Cassell \& Co. London: United Kingdom.

Jeelani SM, Kumari S, Gupta RC 2012. Meiotic studies in some selected angiosperms from the Kashmir Himalayas. J. Sys. Evol. 50: 244-257.

Kubeczka KH 1982. Chemical investigations of essential oils of Umbellifers In: N. Margaris, A. Koedam, D. Vokou, eds. Aromatic Plants: Basic and Applied Aspects. Netherlands: Martinus Nijhoff Publishers Leiden, pp. 165-173.

Metcalfe CR and Chalk L 1950. Anatomy of The Dicotyledons (Leaves, stem and wood in relation to taxonomy with notes on economic uses), Vol: 1, Amen House, London: Oxford University Press, pp. 712-724.

Metcalfe CR and Chalk L 1979. Anatomy of the Dicotyledons (Systematic anatomy of leaf and stem, with a brief history of the subject), Oxford, UK: Clarendon Press, pp. 1-276.

Ozcan M and Eminagaoglu A 2014. Stem and leaf anatomy of three taxa in Lamiaceae. Bangladesh J. Bot. 43(3): 345-352.

Plunkett GM, Pimenov MG, Reduron JP, Kljuykov EV, Lee BY, Van Wyk BE,. Tilney PM, Watson MF, Ostroumova TA, Spalik K, Hart JM, Henwood MJ, Webb CJ, Pu FD, Mitchell AD and Muckensturm B 2014. Apiaceae. In: Kubitzki K. (ed.) The Families and Genera of Vascular Plants, Springer-Verlag, Berlin, Germany.

Psaroudaki A, Dimitropoulakis P, Constantinidis T, Katsiotis A and Skaracis GN 2012. Ten indigenous edible plants: Contemporary use in Eastern Crete Greece. Culture Agricul. Food Enviro. 34: 172-177.

Satil F, Aslan M, Erdogan E, Polat R and Selvi S 2015. Comparative anatomical studies on some species of Hyoscyamus L. (Solanaceae) growing in Turkey. Bangladesh J. Bot. 44(1): 37-43.

Selvi S, Paksoy MY, Polat R and Cakilcioglu U 2013. Micromorphological and anatomical characteristics of the Genus Chrysophthalmum Schultz Bip. (Asteraceae) growing in Turkey. Proceedings Nat. Acad. Scie. India Sect. B: Biol. Scie. 84: 431-438.

Storkey J, Moss S and Cussans J 2010. Using assembly theory to explain changes in a weed flora in response to agricultural intensification. Weed Scie. Soci. 58: 39-46.

Tsakalidi AL 2014. Scandix pecten-veneris L.: A wild green leafy vegetable. Australian J. Crop Scie. 8: 103108.

Urusak EA and Kizilarslan C 2013. Fruit anatomy of some Ferulago (Apiaceae) species in Turkey. Turk. J. Bot. 37: 434-445.

Watson L and Dallwitz MJ 2000. The Families of Flowering Plants: Descriptions, Illustrations, Identification, and Information Retrieval. Version: $14^{\text {th }}$.

Zohary M 1972. Flora Palaestina 2. The Israel Academy of Sciences and Humanities, Jerusalem. 